ORIGINAL ARTICLE

\title{
Short term changes in lung function, leukocytosis in blood, and lachrymal fluid among bacterial single cell protein workers after an episode with high exposure to endotoxins
}

\author{
M Skogstad, W Eduard, J Holme, T Qvenild, E Einarsdottir
}

Occup Environ Med 2005;62:576-580. doi: 10.1136/oem.2004.019273

See end of article for authors' affiliations

....................

Correspondence to: Dr M Skogstad, National Institute of Occupational Health, PO Box 8149 Dep, $\mathrm{N}-0033$ Oslo, Norway; Marit.Skogstad@stami.no

Accepted 4 March 2005

\begin{abstract}
Aims: To study possible effects of endotoxin exposure among bacterial single cell protein workers on pulmonary function, blood parameters, and lachrymal fluid before and after a work shift. Methods: The study included 23 men and five women who were examined at the start and at the end of a work shift. Most workers performed a task with unusually high exposure levels. Twelve of the workers were re-examined the day after. The workers were divided into three exposure groups: production workers with the highest assumed exposure levels $(n=18)$, engineers $(n=5)$, and clerks $(n=2)$. The median endotoxin level during a work shift was $34000 \mathrm{EU} / \mathrm{m}^{3}$ in the high exposure group (range 3300-89000 EU/ $\mathrm{m}^{3}$ ), $11000 \mathrm{EU} / \mathrm{m}^{3}$ (range 350-27000 EU/m ${ }^{3}$ ) among the engineers, and $180 \mathrm{EU} / \mathrm{m}^{3}$ (range 60-300 EU/ $\mathrm{m}^{3}$ ) for the clerks. The workers answered a questionnaire about work related symptoms. Assessment of lung function included dynamic lung volumes and flows. The blood analysis included cell count of leukocytes and mediators of inflammation, fibrinogen, interleukin-6 (IL-6), D-dimer, and C-reactive protein (CRP). Cells in lachrymal fluid were counted with a microscope.

Results: The forced vital capacity (FVC) changed significantly ( $<<0.05$ ) from 5.34 I (SD 0.9) to 5.25 I (SD 0.9) and forced expired volume in one second (FEV1) from 4.15 I (SD 0.7) to 4.07 I (SD 0.7) during the work shift. The leukocytes increased significantly $(p<0.05)$ from $6.910^{9} /$ I (SD 1.2) to $7.710^{9} /$ I (SD 1.5) and IL-6 from $1.5 \mathrm{ng} / \mathrm{I}$ (SD 0.6) to $3.31 \mathrm{ng} / \mathrm{I}$ (SD 2.7). Except for fibrinogen, which had a borderline increase and PEF that decreased, the parameters were normalised the day after. Four of the workers had an increase of neutrofile granulocytes in the lachrymal fluid during the shift. There was a significant association between the endotoxin concentration and decrease of FEVI despite the use of powered respirators.

Conclusions: During a work shift with unusual high levels of endotoxins at a plant manufacturing bacterial single cell protein the results show that FVC and FEVI were reduced. Mediators of inflammation increased along with leucocytosis in blood and lachrymal fluid among the workers.
\end{abstract}

W orkers in a plant producing bacterial single cell protein (SCP), a protein product used in animal feed, complained of attacks of fever, fatigue, chest tightness, skin dryness/eczema, and rubor and inflammation of the eyes after episodes with high exposure. The product they manufacture is dried bacterial mass mainly from a single species, Methylococcus capsulatum. This organism is a gram negative bacterium and contains endotoxins.

The phenomenon the SCP workers described resembles ODTS (organic dust toxic syndrome), which is known from studies among cotton workers, sawmill workers, and farm$\mathrm{ers}^{1-3}$ who can be highly exposed to spores from fungi and actinomyces $^{4}$ or endotoxins. ${ }^{5}$ In these studies workers are exposed to a mixture of organic dust components. SCP production is interesting as the organic dust exposure is mainly caused by a single organism. Two studies have been published describing SCP production workers exposed to the gram negative bacteria Methylophilus methylotrophus ${ }^{6}$ and Methylomonas methanolytica, ${ }^{7}$ respectively. These workers experienced similar reactions that were ascribed to endotoxins.

The aim of the present study was to study short term changes in pulmonary function and indicators of inflammation in the blood and lachrymal fluid, work related symptoms and possible associations to endotoxin exposure after an extraordinary highly exposed task was carried out by the workers.

\section{MATERIAL AND METHODS}

The workers consisted of 28 individuals, including 21 production operators, five engineers, and two office workers. Five of these were women. All workers were examined before and after a work shift, and 12 of the workers were reexamined the day after. One production operator did not complete the symptoms questionnaire and measurements of blood parameters excluded three production operators because of technical failure. In addition, the laboratory could only contribute to 16 measurements of IL-6, CRP, D-dimer, and fibrinogen. Before this work shift the workers' exposure had been sparse for more than 12 weeks. Some pellets were produced but otherwise ordinary production was carried out. The mean age of the workers was 35 years (range 2551 years). Seven of the workers (25\%) were smokers smoking between one and 20 cigarettes each day. The mean height of the group was $178 \mathrm{~cm}$ (range 153-195 cm).

The study was approved by the Regional Ethical Committee for Medical Research in Trondheim, Norway. All participants gave their written informed consent at the start of the study. Anonymity of the subjects was secured.

Abbreviations: CRP, C-reactive protein; EU, endotoxin unit; FVC, forced vital capacity; FEVI, forced expiratory volume in 1 second; IL-6, interleukin-6; SCP, single cell protein 


\begin{tabular}{|c|c|c|c|c|}
\hline \multirow{2}{*}{$\begin{array}{l}\text { Worker } \\
\text { category }\end{array}$} & \multirow{2}{*}{$\begin{array}{l}\text { Respiratory } \\
\text { protection }\end{array}$} & \multirow[b]{2}{*}{ n } & \multicolumn{2}{|c|}{$\begin{array}{l}\text { Endotoxin concentration, } \\
\mathrm{EU} / \mathrm{m}^{3}\end{array}$} \\
\hline & & & $\mathrm{GM}^{*}$ & GSD $†$ \\
\hline Production & Yes & 17 & 24000 & 2.8 \\
\hline operator & No & 1 & 4300 & - \\
\hline \multirow{2}{*}{ Engineer } & Yes & 3 & 9400 & 5.8 \\
\hline & No & 2 & 830 & 3.3 \\
\hline Administrative & No & 2 & 140 & 3.2 \\
\hline
\end{tabular}

${ }^{*} G M$, geometric mean

TGSD, geometric standard deviation.

\section{Exposure}

The production workers emptied big bags with SCP during the shift. The engineers also participated partly in this work. The endotoxin level was therefore expected to be extraordinarily high. One of the two white collar workers visited the production area for a short period.

Personal samples of inhalable dust were collected during the whole work shift on glass fibre filters (Whatman GF/A, Maidstone, MA, USA) in PAS6 cassettes ${ }^{8}$ with a flow rate of 2 l/min using portable pumps. Endotoxins were measured by the kinetic LAL method at the laboratory of the company. The reproducibility was $16 \%$ (relative standard deviation) estimated from replicate analysis $(n=3-6)$ of a total of 50 samples analysed on different plates. Field blanks $(\mathrm{n}=8)$ showed an arithmetic mean level of 3 (SD 2.5) endotoxin units (EU).

Assessment of blood parameters and lachrymal fluid Blood samples of the workers $(n=25)$ were taken before and after the work shift and for 12 workers the day after as well. Leukocytes were analysed using haemocytometry before and after the work shift at a commercial laboratory in Oslo. ${ }^{9}$ The mediators of inflammation interleukin-6 (IL-6), D-dimer, fibrinogen, and CRP were measured in serum after coagulation for 30 minutes at room temperature and centrifugation for 10 minutes at $1000 \mathrm{~g}$ (IL-6) or $2000 \mathrm{~g}$ (D-dimer, fibrinogen, and CRP). Serum was then kept at $-20^{\circ} \mathrm{C}$ in cryotubes until analysis within a month. IL-6 was measured with the commercial enzyme linked immunosorbent assay (ELISA) kit Quantikine HS (R\&D Systems, UK). For the in vitro quantitative determination of CRP in human serum and plasma an immunoturbidimetric assay on Roche automated clinical chemistry analysers was used (Roche, Mannheim, Germany). The fibrinogen concentration in plasma was measured with a Fibri-Prest (Paris, France) automate using the clotting method of Clauss. ${ }^{10}$ These blood analyses were

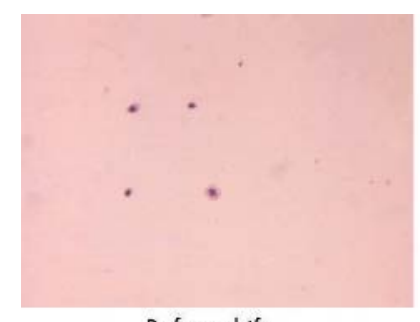

Before shift

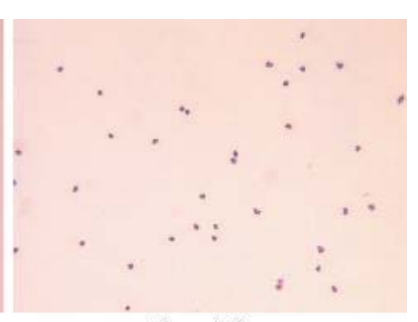

After shiff
Figure 1 Stained cells in lachrymal fluid before and after the work shiff from one worker viewed with a light microscope at a magnification of $400 \times$. Before work one leukocyte and three epithelial cells and after work shift abundant numbers of neutrofile granulocytes were observed (original magnification $\times 400$ in both).

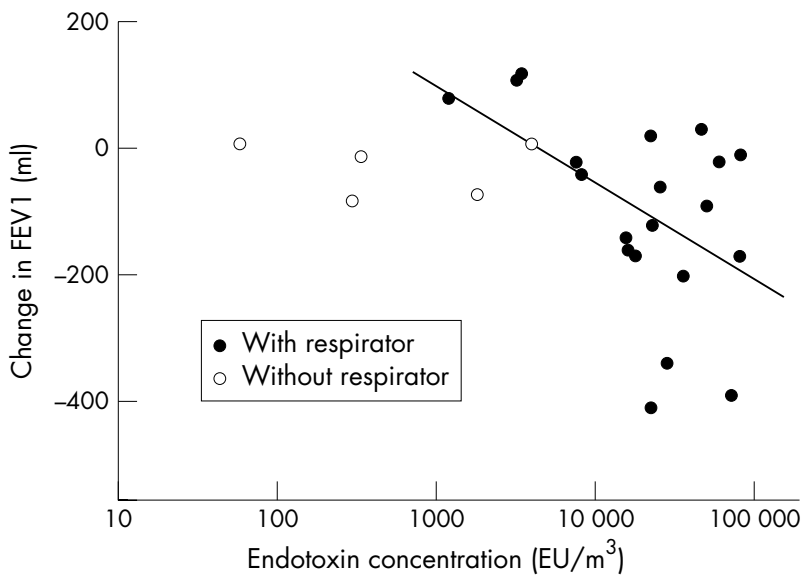

Figure 2 Lung function decline (FEV1) associated with an increase in concentration of endotoxins. Most operators used respirators $(n=20)$ and the regression line of this group is shown. The regression coefficient was $-0.15 \mathrm{I}(95 \% \mathrm{Cl}-0.28$ to -0.02$), p=0.03 r_{\text {adj }}^{2}=0.21$, for the $\log _{10}$ transformed endotoxin concentrations.

performed at the department of Clinical Chemistry at the University Hospital of Trondheim, Norway.

As for the ocular tests, two drops of physiological saline (Drop.it, Gällivare, Sweden) were deposited in one eye of each subject $(\mathrm{n}=23)$ before and after the work shift. A sample of lachrymal fluid was taken from the eye using a disposable Pasteur pipette and then placed on an object glass where it was spread out and left to air dry. Afterwards the sample was stained (according to the May-Grünwald-Giemsa technique) and fitted with a cover glass for microscope analysis. A total of 46 samples were evaluated. Samples were analysed blind by one technician (that is, without knowledge of the origin of the sample). Cells were counted in 100 fields at $400 \times$ magnification using bright field illumination in a Nikon Labophot light microscope. Poorly preserved cells were not included in the count.

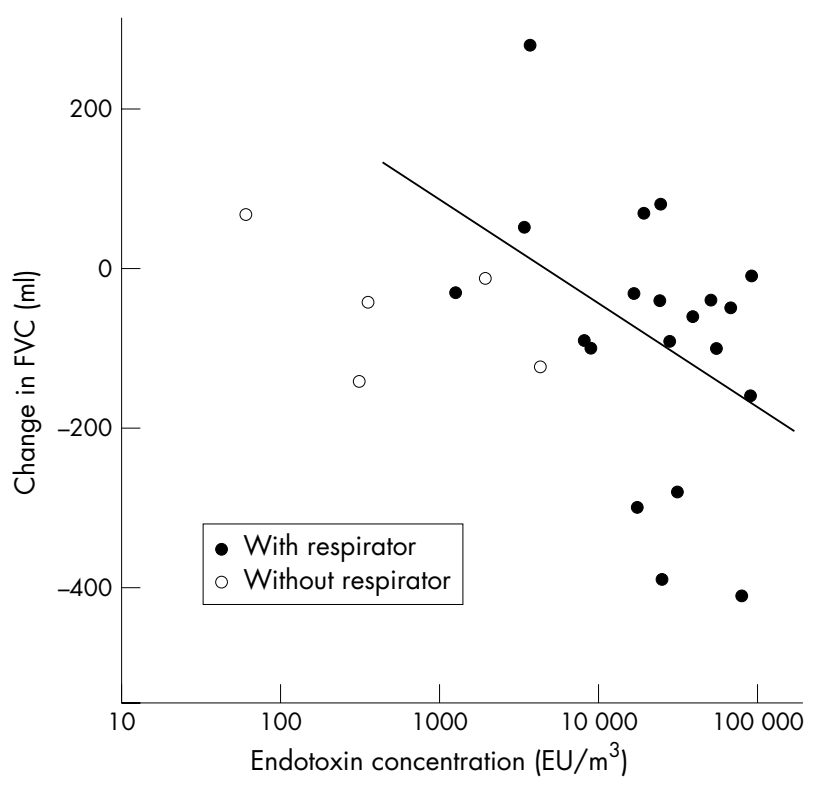

Figure 3 Lung function decline (FVC) associated with an increase in concentration of endotoxins. Most operators used respirators $(n=20)$ and the regression line of this group is shown. The regression coefficient was -0.13 I (95\% Cl -0.28 to +0.02$), p=0.08, r_{\text {adj }}^{2}=0.11$, for the $\log _{10}$ transformed endotoxin concentrations. 
Table 2 Change in lung function and inflammatory parameters in blood during a work shift

\begin{tabular}{|c|c|c|c|c|c|c|}
\hline \multirow[b]{2}{*}{ Parameter } & \multirow[b]{2}{*}{ No } & \multirow{2}{*}{$\frac{\text { Before work }}{\text { Mean (SD) }}$} & \multirow{2}{*}{$\frac{\text { After work }}{\text { Mean (SD) }}$} & \multicolumn{2}{|l|}{ Difference } & \multirow{2}{*}{$\begin{array}{l}\text { Paired } \\
t \text { test } \\
\text { P value }\end{array}$} \\
\hline & & & & Mean (SD) & $95 \% \mathrm{Cl}$ & \\
\hline$\overline{F V C ~(I) ~}$ & 28 & $5.34(0.9)$ & $5.25(0.9)^{*}$ & $-0.08(0.17)$ & -0.15 to -0.02 & 0.02 \\
\hline FEVI (I) & 28 & $4.15(0.7)$ & $4.07(0.7)^{*}$ & $-0.08(0.18)$ & -0.15 to -0.01 & 0.03 \\
\hline $\mathrm{FEF}_{25-75 \%}(\mathrm{l} / \mathrm{s})$ & 28 & $3.81(1.3)$ & $3.70(1.2)$ & $-0.11(0.48)$ & -0.30 to 0.07 & 0.2 \\
\hline $\mathrm{PEF}(\mathrm{I} / \mathrm{s})$ & 28 & 758 (148) & 770 (149) & $12(78)$ & -18 to 43 & 0.4 \\
\hline White blood cells $\left(10^{9} / \mathrm{l}\right)$ & 25 & $6.9(1.2)$ & $7.7(1.5)^{*}$ & $0.8(1.5)$ & 0.21 to 1.4 & 0.01 \\
\hline IL-6 (ng/l) & 16 & $1.5(0.6)$ & $3.31(2.7)^{*}$ & $1.8(2.4)$ & 0.51 to 3.1 & $<0.01$ \\
\hline Fibrinogen (g/l) & 16 & $2.56(0.4)$ & $2.55(0.7)$ & $0.01(0.6)$ & -0.31 to 0.29 & 0.9 \\
\hline
\end{tabular}

\section{Pulmonary function tests}

The pulmonary function testing was performed using the Vitalograph 2170 spirometer (Spirotrac, Vitalograph Ltd, Buckingham, UK). The same technician performed all tests. The workers were given standardised instructions on the forced maximal expiratory manoeuvres, with demonstration of the procedures. The tests were performed with the subjects sitting in a chair and breathing through a mouth piece with a nose clip. The spirometer was calibrated daily. The best results, according to ATS criteria, of at least three flow volume manoeuvres were used in the analysis. ${ }^{11}$ Peak expiratory flow rate (PEF), forced vital capacity (FVC), forced expired volume in one second (FEVI), and forced mid-expiratory flow rate $\left(\mathrm{FEF}_{25-75 \%}\right)$ were measured.

\section{Statistical methods}

Standard measures of central tendency and distributions (arithmetic means and standard deviations) were computed. Exposure data were highly skewed and were log transformed before statistical analysis. Student's paired $t$ tests were used to compare continuous outcomes before and after the work shift. Repeated measures ANOVA was used on data also including the day after. Simple linear regression analysis was used to find possible effects of endotoxins on change in FVC and FEVl. Comparison between operator with and without symptoms was performed by $t$ tests for unequal variances. All tests were two sided and a significance level of 5\% was chosen. ${ }^{12}$ SPSS for Windows 12.0 (SPSS Inc, Chicago, IL, USA) was used in the data analysis.

\section{RESULTS}

\section{Exposure}

The endotoxin levels are shown in table 1. The workers used positive pressure respirators and disposable overalls, and the measured concentrations overestimate actual exposure levels to a large extent. Five workers who did not use respiratory protection during work were exposed to lower endotoxins levels. However, the measurements exceeded $200 \mathrm{EU} / \mathrm{m}^{3}$ for four workers and had a geometric mean of $1200 \mathrm{EU} / \mathrm{m}^{3}$.

\section{Health effects}

Lung function and blood parameters before and after the work shift of 28 workers are shown in table 2 . There were significant decreases in FVC and FEVl during the work shift of $90 \mathrm{ml}$ and $80 \mathrm{ml}$ on average, respectively. The white blood cell count and IL-6 increased significantly with $12 \%$ and $120 \%$, respectively.

Lung function values and IL-6 returned to before shift levels the day after except for PEF which was significantly decreased (table 3). Fibrinogen showed, however, a borderline increase (table 3). Two of the workers had an increased CRP from 7 to $15 \mathrm{mg} / \mathrm{l}$ and 5 to $24 \mathrm{mg} / \mathrm{l}$, respectively during work shift. Both workers had exposure levels below $550 \mathrm{EU} /$ $\mathrm{m}^{3}$. There were no changes among the other operators during shift but the detection level was $5 \mathrm{mg} / \mathrm{l}$. In one worker an increase in D-dimer was recorded.

Six workers of a total of 23 workers with lachrymal examination returned after shift with rubor, injection and two of the six visible pus in their eyes. Cell counts in the lachrymal fluid are shown in table 4 . Figure 1 shows the visible changes in the microscope for one of the workers before and after the shift at work ended. No changes were detected among the other workers.

A few work related symptoms were reported. Dry skin/ eczema was reported by more than half of the workers (table 5), fever reactions during and/or after work were reported by four workers, and eye irritations during and/or after work were reported by six workers.

\section{Associations between outcome and exposure}

A significant association between the log transformed endotoxin concentration and decrease in FEVI during the work shift among operators that used respirators was found by linear regression $(p=0.03$ ) (fig 2 ). The association between FVC and endotoxin was of borderline significance $(p=0.08)$ (fig 3). When endotoxin levels of workers that used respiratory protection were arbitrarily assigned to $10 \%$ of the measured endotoxin concentrations the association with FEVl remained $(p=0.02)$, and a significant association

Table 3 Change in lung function and inflammatory blood parameters during a work shift in addition to the results the following day $(n=12)$

\begin{tabular}{|c|c|c|c|c|c|c|}
\hline & \multirow{2}{*}{$\begin{array}{l}\text { Before shift } \\
\text { Mean (SD) }\end{array}$} & \multirow{2}{*}{$\begin{array}{l}\text { After shift } \\
\text { Mean (SD) }\end{array}$} & \multirow{2}{*}{$\begin{array}{l}\text { Following day } \\
\text { before shift } \\
\text { Mean (SD) }\end{array}$} & \multicolumn{2}{|c|}{ Difference before shift and day after } & \multirow{2}{*}{$\begin{array}{l}\text { Paired } t \text { test before shift } \\
\text { and day after } p \text { value }\end{array}$} \\
\hline & & & & Mean (SD) & $95 \% \mathrm{Cl}$ & \\
\hline FVC (I) & $5.35(0.8)$ & $5.18(0.8)$ & $5.29(0.9)$ & $-0.06(0.23)$ & -0.21 to 0.09 & 0.4 \\
\hline FEVI (I) & $4.24(0.7)$ & $4.09(0.6)$ & $4.18(0.7)$ & $-0.07(0.18)$ & -0.18 to 0.05 & 0.2 \\
\hline $\mathrm{FEF}_{25-75 \%}(\mathrm{l} / \mathrm{s})$ & $4.14(1.6)$ & $3.91(1.4)$ & $3.90(1.3)$ & $-0.23(0.56)$ & -0.59 to 0.12 & 0.2 \\
\hline $\operatorname{PEF}(\mathrm{I} / \mathrm{s})$ & $766(153)$ & $765(166)$ & 724 (159) & $-42(57)$ & -78 to -6 & 0.03 \\
\hline White blood cells $\left(10^{9} / \mathrm{L}\right)$ & $6.8(1.3)$ & $7.2(1.5)$ & $7.2(1.1)$ & $0.43(1.3)$ & -0.41 to 1.3 & 0.2 \\
\hline IL-6 (ng/l) & $1.64(0.6)$ & $3.60(2.9)$ & $1.83(0.9)$ & $0.19(0.87)$ & -0.37 to 0.74 & 0.5 \\
\hline Fibrinogen (g/l) & $2.63(0.39)$ & $2.51(0.64)$ & $2.88(0.35)$ & $0.26(0.43)$ & 0.01 to -0.53 & 0.06 \\
\hline
\end{tabular}




\begin{tabular}{|c|c|c|c|c|}
\hline \multirow[b]{2}{*}{ Case } & \multicolumn{2}{|c|}{ Epithelial cells } & \multicolumn{2}{|l|}{ Leukocytes } \\
\hline & Before shift & After shift & Before shift & After shift \\
\hline 1 & 76 & 0 & 0 & 196 \\
\hline 2 & 0 & 0 & 0 & 8 \\
\hline 3 & 0 & 0 & 0 & 0 \\
\hline 4 & 8 & 0 & 1 & 619 \\
\hline 5 & 5 & 0 & 0 & 2 \\
\hline 6 & 0 & 0 & 0 & 0 \\
\hline
\end{tabular}

with FVC was found $(p=0.05)$. FEVl decreases mainly occurred at exposure levels greater than $1000 \mathrm{EU} / \mathrm{m}^{3}$ when adjusted for respirator use. Only a small drop in FEVl was observed among workers not using respirators (arithmetic mean $-28 \mathrm{ml}$ ).

As for the questionnaire few symptoms were reported. However, for fever reaction (only two symptomatic workers with exposure data) and dry skin/eczema significant associations were found with increased endotoxin concentration: $p<0.01$ and $p=0.04$, respectively. The $\log _{10}$ exposure differences were $-0.92(95 \% \mathrm{CI}-1.32$ to -0.52$)$ and -0.75 (95\% CI -1.47 to -0.04$)$ corresponding to eight and six times higher exposure among the symptomatic operators. Endotoxin concentrations measured on the workers reporting fever were the highest and the fourth highest measured values, 65000 and $89000 \mathrm{EU} / \mathrm{m}^{3}$. In association with dry skin/eczema the endotoxin concentration in air is probably a surrogate for skin exposure.

\section{DISCUSSION}

We have found a decrease in FVC and FEVl during a work shift with high exposure along with peripheral blood leucocytosis and increase in IL-6 and a borderline increase in fibrinogen one day later among workers in a bacterial single cell protein plant. As for the decrease in FEVl, there was an association with increased levels of endotoxin and a borderline association for FVC. In addition, a reaction of the conjunctiva with white blood cells in the lachrymal fluid was observed among some of the workers. Four workers reported fever reactions and endotoxin measurement performed on two of these workers showed very high levels. Skin symptoms were reported by more than half of the workers.

Temporary decreases in FVC and FEVI have been demonstrated for workers in the cotton industry, workers in the animal feed production, farmers, and in mechanical industries where exposure for endotoxins is present. ${ }^{13}$ These changes were also associated with endotoxin exposure level as in the present study. Some of these studies suggest noeffect levels of less than $100 \mathrm{EU} / \mathrm{m}^{3}$. However, inhalation studies suggest that an inhaled dose of 30-40 $\mu$ g or more of pure endotoxin is needed to induce a decrease in FEVI in healthy subjects. ${ }^{14}$ This is a much larger dose compared with the dose the workers in this study and other epidemiological studies inhaled. The reason for the difference between experimental and epidemiological studies is not understood. The present study suggests a no-effect level for endotoxin of $1000 \mathrm{EU} / \mathrm{m}^{3}$ with considerable uncertainty because of the small size of the population and the use of respirators. But even if the protection from respirators was smaller than assumed, our results still show FEVI declines at much lower levels than those used in human challenge studies.

As for the inflammatory response in the present study, the leukocytes in blood and IL-6 increased during the work shift while fibrinogen showed a borderline significant increase the day after. These changes are in agreement with the threshold
Table 5 Self reported work related symptoms during work $(n=27)$

\begin{tabular}{lcr}
\hline & \multicolumn{2}{l}{ Prevalence } \\
\cline { 2 - 3 } Symptom & $\mathbf{n}$ & $\%$ \\
\hline Eye irritation & & \\
$\quad$ During work & 3 & 22 \\
$\quad$ After work & 2 & 11 \\
Nose irritation & 3 & 7 \\
Sore throat & 2 & 7 \\
Cough & 0 & 0 \\
Wheezing/chest tightness & 15 & 56 \\
Dry skin/eczema & 0 & 0 \\
Urticaria & 3 & 11 \\
Fever & 2 & 7 \\
$\quad$ During work & 0 & 0 \\
$\quad$ After work & 1 & 4 \\
Gastrointestinal complaints & 0 \\
Malaise/tiredness & & \\
\hline &
\end{tabular}

dose of pure inhaled endotoxin inducing changes in blood neutrophils, which is less than $0.5 \mu \mathrm{g}$ in human volunteers ${ }^{14}$ corresponding to less than $1000 \mathrm{EU} / \mathrm{m}^{3}$. IL-6 can be produced in the mucous membrane of the bronchus, which subsequently can stimulate the production of fibrinogen in the liver. ${ }^{15}$ It has also been shown that human volunteers exposed to high levels of organic dust containing endotoxins in a pig house get an increase of $\mathrm{IL}^{-} 6^{16}$ and later on an increase of fibrinogen in blood ${ }^{17}$ similar to the workers in this study. Increased fibrinogen is of concern because increased levels of fibrinogen have been associated with an increased risk for coronary heart disease and diabetes II. ${ }^{18-20}$

In the present study we also found that the irritation in the eyes reported by the workers before the study is caused by a transient inflammation. This has been reported in another study of technicians producing bacterial single cell protein. ${ }^{6}$ The size and the composition of the particles are probably important factors. The single cell protein at the plant studied contains relatively large particles $(>100 \mu \mathrm{m})$, which can be deposited in the eyes. In addition bioprotein particles are composed of almost pure bacterial mass while the bacterial content of organic dust in other settings is much lower.

Fever attacks were reported by three of the workers in this study on a single day. In a Swedish study of eight technicians working with production of a single cell protein based on Methylomonas methanolytica, seven of them reported attacks of fever at least once ${ }^{8}$ which was interpreted as a toxic reaction caused by endotoxins. Similar reactions have also been reported by Mayes $^{6}$ concerning a product based on Methylophilus methylotrophus (Pruteen). The rather moderate symptoms reported in these studies among those exposed to this product could be caused by the addition of oil to the product, which reduced the generation of airborne dust. Furthermore, in the present study the exposure levels represent a worst case situation.

No workers had quit work because of health problems after the plant had started production in 1998. All workers participated in the study and we therefore believe that the population is representative for the Norwegian working population.

The endotoxin measurements give only a crude estimate of the real exposure as we have no quantitative information on the effectiveness of the personal protective equipment used by the workers during the work shift. Thus, both overestimation and underestimation of the exposure is possible, when we adopted a protection factor of 10. A British standard lists protection factors of $10-40$ for such devices. ${ }^{21}$ That means that one can assume that the respirators provide an exposure reduction of $90-97.5 \%$. The workers did not use the 
respirators during the whole shift and it was not feasible to obtain information on the duration of respirator use. However, the workers used respirators whenever they performed exposed tasks, as they were familiar with acute effects from high exposure episodes. Deposition of dust in the exhalation tube indicated that unfiltered air may have been inhaled. In addition, it should be expected that the size of this error differs across the samples which attenuates an association between exposure and outcome. However, the associations between exposure and effect were significant in a relatively small population which suggest that the association is strong.

Adjustments for smoking and age were not applied due to the small size of the population and because the cross shift design removes these sources of confounding, as the subjects are their own controls.

A mechanism that would explain the symptoms and effects observed in this study would be an inflammatory response after inhalation of bacterial endotoxins. Endotoxins or the lipopolysaccarides in the bacterial single cell protein have macrophages and epithelial cells in the lung as target cells. Stimulation of the macrophages can give a rapid influx of neutrophile granulocytes in the lung, platelets can stick to the vessel wall, and endothelial cells can be damaged. The activation of macrophages can give production of chemotactic factors in blood such as TNF $\alpha$, IL-1, IL-6, and oxygen metabolites promoting inflammatory changes in the airways and system reactions such as fever and leucocytosis. ${ }^{14}$ The lower dose of endotoxin needed to induce respiratory effects compared to human challenge with purified endotoxin either indicates that the toxicity of the endotoxins is different or that there are synergistic effects from other bacterial components.

In conclusion, the results obtained during a work shift show a temporary reduction in FVC and FEVl, the latter associated with the endotoxin level in a bacterial aerosol. An increase in blood leukocytes and inflammation mediators was found during work shift and fibrinogen was increased the day afterwards. For some of the workers eye inflammation was observed and others experienced fever attacks and dermatitis. These findings warrant a further follow up of this group of workers.

\section{ACKNOWLEDGEMENTS}

This study was supported financially by Statoil's Fund for Research in Occupational Medicine, Oslo, Norway. The workers and staff of the company are gratefully acknowledged for participation in the study and Per Ole Huser, National Institute of Occupational Health, for participation in the field work.
Authors' affiliations

M Skogstad, W Eduard, E Einarsdottir, National Institute of

Occupational Health, PO Box 8149 Dep, NO-0033 Oslo, Norway

J Holme, T Qvenild, Occupational Department, St Olavs Hospital,

NO-7000 Trondheim, Norway

\section{REFERENCES}

1 Christiani DC, Wang XR, Pan LD, et al. Longitudinal changes in pulmonary function and respiratory symptoms in cotton textile workers. A 15-yr follow-up study. Am J Respir Crit Care Med 2001 ; 163:847-53.

2 von Essen S, Robbins RA, Thompson $A B$, et al. Organic dust toxic syndrome: an acute febrile reaction to organic dust exposure distinct from hypersensitivity pneumonitis. Clin Toxicol 1990;28:389-420.

3 Rask-Andersen A. Organic dust toxic syndrome among farmers. Brit J Ind Med 1989;189:46:233-8.

4 Malmberg P, Rask-Andersen A, Palmgren U, et al. Respiratory problems among Swedish farmers, correlation between symptoms and environment. Eur J Respir Dis 1987;71(Suppl 154):22-7.

5 Rylander R. Evaluation of the risks of endotoxin exposures. Int J Occup Environ Health 1997;3(Suppl):32-6.

6 Mayes RW. Lack of allergic reactions in workers exposed to Pruteen (bacterial single-cell protein). Brit J Ind Med 1982;39:183-6.

7 Ekenvall L, et al. Single cell protein as an occupational hazard. Brit J Ind Med 1983;40:212-15.

8 van der Wal JF. Comparative measurements of the total dust concentration at the work place with different samplers - Part I. Staub - Reinhalt [in German]. Luff 1983;43:291-4.

9 Lewis SM, England JM, Kubota F. Coincidence correction in red blood cell counting. Phys Med Biol 1989;34:1239-46.

10 Clauss A. Gerinnungsphysiologische Schnellmetode zur Bestimmung des Fibrinogen. Acta Haematol 1957; 17:237-46.

11 American Thoracic Society. Standardization of spirometry-1987 update. Am Rev Respir Dis 1987; 136:1285-98.

12 Altman DG. Practical statistics for medical research. London, UK: Chapman \& Hall, 1995.

13 Douwes J, Heederik D. Epidemilogic investigations of endotoxins. Int J Occup Environ Health 1997;3(Suppl):26-31.

14 Thorn J. The inflammatory response in humans after inhalation of bacterial endotoxin: a review. Inflamm Res 2001;50:254-61.

15 Siögren B. Occupational exposure to dust: inflammation and ischaemic heart disease. Occup Environ Med 1997;54:466-9.

16 Wang Z, Malmberg P, Larsson P, et al. Time course of interleukin- 6 and tumor necrosis factor-a increase in serum following inhalation of swine dust. Am J Respir Crit Care Med 1996;153:147-52.

17 Siögren B, Wang Z, Larsson BM, et al. Increase in Interleukin- 6 and fibrinogen in peripheral blood after swine dust inhalation. Scand J Work Environ Health 1999;25:39-41.

18 Ma J, Hennekens CH, Ridker PM, et al. A prospective study of fibrinogen and risk of myocardial infarction in the Physicians' Health Study. JACC 1999;33:1347-52.

19 Lind P, Hedblad B, Stavenow L, et al. Influence of plasma fibrinogen levels on the incidence of myocardial infarction and death is modified by other inflammation-sensitive proteins. A long-term cohort study. Arterioscler Thromb Vasc Biol 2001;21:452-8.

20 Pradhan AD, Manson JE, Rifai N, et al. C-reactive protein, interleukin 6, and risk of developing type 2 diabetes mellitus. JAMA 2001;286:327-34.

21 British Standard. Guide to implementing an effective respiratory protective device programme. BS 4275:1997. BSI:UK. 